Cadernos de Literatura em Tradução, n. 5, p. 43-58

\title{
Poe-tando o Corvo
}

Isa Mara Lando

No início de 2001 o prezado colega Haroldo Netto lançou um desafio na lista Litterati, de tradutores literários, à qual pertenço: fazer uma nova tradução do famoso poema "The Raven" de E. A. Poe. Minha vontade de tentar foi imediata: amo Poe desde a adolescência, já traduzi outros poetas, como Baudelaire, Emily Dickinson e John Lennon, com resultados razoáveis, e como todo o mundo, também cometi meus poemas de juventude. Além disso já traduzi dois contos de Poe, "A Carta Roubada" e "Os Assassinatos da Rua Morgue" (reunidos num livrinho bilingüe em edição Imago/Alumni). Essas versões me pareceram bastante satisfatórias, mostrando que minha afinidade com Poe me permitia, pelo menos, tentar. Como disse Chico Buarque, "a melhor inspiração é a encomenda"...

Comecei relendo as consagradas traduções de Fernando Pessoa e Machado de Assis**. São belas, claro, sobretudo a de Fernando Pessoa, fiéis ao tom erudito do original, com belos momentos como "Noite, noite e nada mais" (FP). Mas por serem já antigas, e ambas de dicção lusitana, achei-as duras, dificultosas, com palavras e frases que para um leitor brasileiro de hoje causam espécie e distanciamento, como:

"Tens o aspecto tosquiado"

"Por certo", disse eu, "aquela bulha é na minha janela."

"Libertar-se-á... nunca mais!"

"Vou sentar-me defronte ao Corvo magro e rudo" 
"Onde as tranças angelicais / De outra cabeça outrora ali se desparziam / E agora não se esparzem mais."

Já foi dito que cada geração traduz de novo os clássicos, e é bom que assim seja. E ao constatar que circulam na internet não só estas como diversas outras traduções do poema, em verso e prosa, decidi fazer uma tentativa.

Alguém já disse que o primeiro verso de um poema é dado pelos deuses, ou soprado pelas musas. E de fato, ao mergulhar em "Once upon a midnight dreary..." ouvi distintamente, Meia noite, noite escura

Hora de sombra e loucura...

Um bom começo - sonoro, evocativo, e em redondilha maior, um ritmo tão natural e familiar aos ouvidos brasileiros. Já estava dado o tom, o diapasão, o rumo da coisa toda. Outros versos logo surgiram:

Bate, bate bem de leve

Com batidas repetidas

(Era o Corvo, com certeza, batendo à minha porta, com batidas decididas, numa aliteração quase onomatopéica.) Entrando na segunda estrofe ganhei outro presente das musas: de bandeja, a rima remember /december, aliás aproveitada em muitas traduções:

Eu me lembro, bem lembro,

No triste mês de dezembro...

Um bom clima! $\bigcirc$ ritmo era hipnótico, e o espírito de Poe,nobre e solene, começava a respirar e ganhar vida. Surgia diante de mim a noite negra, o quarto atapetado, o poeta sofredor, a sombra da Casa de Usher, o gato emparedado, o coração delator. Fui ficando empolgada. E foi então que comecei a ouvir os versos na voz de Alceu Valença, e também dos geniais repentistas nordestinos que certa vez assisti num desafio, numa feira no Ceará. Foi Alceu Valença quem me soprou,

Jóia rara, tão fugaz,

Leonor, pra nunca mais! 
"Leonor" - eis uma solução simples e eufônica para "Lenore", mais maleável do que a "Lenora" de Machado. (Fernando Pessoa - que curioso! - deixa a donzela sempre "nameless" - "sem nome aqui jamais".) "Leonor", um nome curto, rima com dor, horror, terror - tudo que eu precisava.

O poema ia assim ganhando forma, com dicção marcadamente brasileira. Acolhi essa vertente de braços abertos: o terror não tem pátria, e pode-se sentir em qualquer lugar, seja em Londres, Baltimore, Nova York ou Fortaleza, o pavor de ver entrar pela janela - meia-noite, noite escura, hora sem sono e sem paz - uma negra criatura que só fala "Nunca Mais".

Continuei assim num semi-transe, meio que servindo de "cavalo" para os repentistas cearenses, Fagner, Chico Buarque, Chico César... No final da estrofe Alceu Valença soltou um nítido grito, com um forte acorde dissonante:

"Escuridão - nada mais!"

O poema bradava, abria as asas, ganhava força, vigor, vida própria. Enquanto a madrugada avançava eu ouvia, mentalmente, as vozes brasileiras. E sobretudo, lá no fundo da mente, o ritmo constante de um poema que amo muito, "A Morte de Madrugada", de Vinícius de Morais***:

Uma certa madrugada

Eu por um caminho andava

Não sei bem se estava bêbado

Ou se tinha a morte n'alma....

...Com o peito de dor rompido

Me quedei, paralisado.....

Prossegui embalada pelas redondilhas, dando-me liberdade, sem me importar com o esquema original das rimas, rimando como dava e quando dava, procurando captar o clima do poema, a dramaticidade que sobe num crescendo incessante, até 
LANDO, Isa M. Poe-tando o Corvo.

chegar à estrofe 15, onde de novo a voz de Alceu Valença lança outro brado de angústia:

Profeta, bicho ruim -

Mas profeta mesmo assim!

chegando ao clímax na 17, onde o poeta solta esses gritos dilacerados,

Deixa a minha solidão!

Deixa o busto de Minerva!

Solta meu coração!

Sai fora da minha porta

Vai embora daqui, ave torta

Vai sem olhar pra trás!

São os célebres versos de Poe que inspiraram a ilustração de Gustave Doré

Leave my loneliness unbroken! - quit the bust above my door! Take thy beak from out my heart, and take thy form from off my door!

A solução de Fernando Pessoa é sonora, mas nela não se vê bico ou garra:

Minha solidão me reste! Tira-te de meus umbrais!

Tira o vulto de meu peito e a sombra de meus umbrais!

Machado de Assis aqui foi menos afortunado, pelo menos para o gosto brasileiro moderno:

Tira-me ao peito essas fatais

Garras que abrindo vão a minha dor já crua. 
Depois dessa memorável noite - que no meu caso não foi escura, mas iluminada por uma bela lua cheia entrando pela janela - passei uns bons quinze dias obcecada, burilando os versos sem parar. Já desligada do original, sentia o poema em português ganhando corpo e adensando a alma - uma alma vibrante, inteira, própria, que já se revelara desde as primeiras palavras que me foram sopradas.

Fiquei, enfim, passavelmente satisfeita com o resultado, como acredito que deva estar também Mr. Poe, na alta nuvem em que hoje habita. Declamado em voz alta, como já tive a oportunidade de fazer, o poema em português funciona, faz bom efeito. A maior crítica que lhe faço é que, bem ao contrário do original, as rimas que consegui são pedestres - porta, torta, morta; nunca mais, demais, jamais. Há também duas grandes licenças poéticas - um acréscimo ao original e um verdadeiro erro conceitual - que deixo por conta do leitor descobrir, mas que a meu ver não atrapalham, só ajudam. Enfim, na frase de Cícero, "Feci quod potui, faciant meliora potentes" - "Fiz o que pude, faça melhor quem puder".

Aqui vai, então, o Corvo de Poe, "que cobri de redondilhas" numa noite de luar. Espero que desfrutem. Críticas e observações serão muito bem-vindas. 
LANDO, Isa M. Poe-tando o Corvo.

\section{O CORVO (1845)}

Para a voz de Alceu Valença -

Um trovador de presença

Que sabe cantar chorando,

Ou p'rum velho repentista

Que lá no Nordeste exista

E saiba triste cantar

As angústias do Edgar.

1

Meia-noite, noite escura

Hora de sombra e loucura

Estou eu meditabundo,

Em devaneio profundo

Velhos papéis a estudar

De sono cabeceando

E já quase dormitando

Quando alguém me bate à porta

- Bate, bate, bem de leve -

Com batidas repetidas

Quem será, nessa hora morta

Que veio me procurar?

Deve ser visita breve

- Bate, bate, bem de leve -

Uma visita de paz

Deve ser visita breve

É só isso, nada mais. 
Eu me lembro, bem me lembro

No triste mês de dezembro

Cada brasa da lareira

Uma sombra projetava

E seu fantasma lançava

Pelo chão a se arrastar.

Esperando o amanhecer

Em vão eu tentava obter

Nos livros da minha estante

Consolo pra minha dor

A dor de perder Leonor

A jovem bela, radiante

Que os anjos chamam Leonor

Jóia rara, tão fugaz

Leonor, pra nunca mais.

3

Cortinas de seda roçavam

E minh'alma ameaçavam

Com fantásticos terrores

Temores que nunca senti.

Pra parar meu coração

Que batia feito louco

Fiquei repetindo um pouco:

"É uma visita que chega

Esperando ali na porta,

Chegou nessa hora morta

Mas visita mal não faz

É só isso, nada mais." 
LANDO, Isa M. Poe-tando o Corvo.

4

Ganhei coragem e disse,

"Meu senhor - minha senhora?

Queira me desculpar

Eu dormitava inda agora

Suas batidas tão leves

Não consegui escutar.

Apesar da hora morta

Vou lhe abrir a minha porta

Vamos ver o que me traz."

Fui e escancarei a porta -

Escuridão, nada mais.

5

Espiei a noite escura

Curioso, temeroso

Tomado por devaneios

Que ninguém ousou sonhar.

Só o silêncio me encarava

E a única palavra

Que ali foi sussurrada

Bem de leve murmurada

Foi um nome: "Leonor?"

Foi o que eu disse baixinho

A resposta o eco traz -

Disse o eco, "Leonor!"

Foi só isso, nada mais. 
6

Voltei então para o quarto

Dentro de mim tudo ardia

Logo alguém bateu à porta

Mais forte agora batia.

Com certeza é a janela

$O$ vento na gelosia

Vamos ver o que há lá fora

Que ameaça vem agora

Calma, meu coração

Não bate tanto assim não

Vou explorar esse mistério

Esse mistério tenaz

Vou explorar esse mistério -

É o vento, nada mais.

7

Abro a janela e ouço

Um esvoaçar de asas -

De súbito entra um Corvo

Solene pássaro antigo

Negro viandante arribado

Lá do fundo do passado

E sem dar nenhum sinal

De querer falar comigo

Feito ilustre cavalheiro

— ou talvez fosse uma dama -

Voou - eu levei um susto -

Passou por cima da cama 
LANDO, Isa M. Poe-tando o Corvo.

Chegou no alto da porta

E foi pousar bem no busto

Da deusa Palas Atena -

- Deusa da sabedoria

Que os meus atos vigia

A que não dorme jamais

Acima da minha porta

Pousou ali, nada mais.

8

Negro pássaro de ébano

Um sorriso me arrancou

Ancião de terno preto

Com jeito de professor

"Tu não és nenhum covarde,

Corvo antigo que chegaste

Do reino da Noite escura

Nessa hora negra, tão tarde

Hora de sombra e loucura

Hora sem sono e sem paz

Qual é o teu nome, pergunto,

Teu nome de grão-senhor

Como é que eles te chamam

Lá na Terra de Ninguém

De onde todo corvo vem?"

Disse o Corvo, "Nunca Mais".

9

Fiquei pasmo, aturdido

Ouvindo um bicho tão feio 
Falar com tanta clareza

Mesmo sem fazer sentido

Pois qual é a criatura

Um mortal entre os mortais

Que já viu, em noite escura

Um animal, uma ave

Chegar em hora tão morta

Voar pra cima da porta

Pousar em cima de um busto

E se chamar "Nunca Mais"?

10

Mas o Corvo ali sozinho

É só isso que falava

Como se toda a sua alma

Coubesse numa palavra

Numa palavra cabia

Pois mais nada ele dizia

E nem uma pena negra

Aquele bicho mexia.

Até que eu falei baixinho,

"Outros amigos partiram

Se foram cedo demais

Este vai partir na aurora

Qual meus sonhos de rapaz,

Que também já foram embora."

Disse o Corvo: "Nunca Mais!" 
LANDO, Isa M. Poe-tando o Corvo.

11

Espantado com a resposta

- Só ela quebrava o silêncio -

Com certeza, pensei eu,

Ele só fala de cor

Com outro mestre aprendeu -

- Alguém que muito sofreu

Angústia, pesar e dor

Destino amargo demais

E já morta a Esperança

Só lhe restou na lembrança

Uma triste litania

Feita de melancolia,

Feita só de "Nunca Mais".

12

Mas o Corvo, sério e grave

De novo me fez sorrir

Puxei cadeira e almofada

Sentei diante da porta,

Da porta, do busto e da ave.

Recostado no veludo

Pensei bem naquilo tudo

$\bigcirc$ que ele queria dizer?

Qual a intenção desse bicho

Tão negro, tão magro, tão feio

Triste e solene demais,

Ave de mau agouro

Que entrou no meu devaneio

Grasnando seu "Nunca Mais"? 
13

E fiquei ali pensando

Só pensando, sem falar.

Os olhos do bicho, em brasa,

No peito me penetravam

E o meu mais fundo queimavam.

Mergulhei num devaneio

A cabeça para trás

Reclinada, a descansar

No macio da almofada -

Roxo veludo brilhante

Com seu reflexo cambiante,

Roxo veludo brilhante

Que ela não vai mais tocar

Não tocará nunca mais!

14

Nisso o ar ficou pesado

Com o incenso perfumado

De serafins que entravam

E bem de leve pisavam

No meu quarto atapetado.

Gritei "Desgraça! O teu Deus

Com esses anjos mandou

Um santo remédio pra dor

Alívio do sofrimento

$O$ bendito esquecimento

Pra não lembrar de Leonor!

Bebe logo esse remédio 
LANDO, Isa M. Poe-tando o Corvo.

E não penses nela mais

Esquece tua Leonor!"

Disse o Corvo, "Nunca Mais!"

15

"Profeta, bicho ruim!

Mas profeta mesmo assim

Sejas pássaro ou diabo

Se o Tentador te mandou,

Ou se alguma tempestade

Nestas plagas te jogou

Ave noturna, soturna

Mensageiro do Terror

Aqui nessa terra deserta

Nessa terra enfeitiçada

Nesse lar mal-assombrado

Mal-assombrado de Horror

Te imploro, diz a verdade!

Um bálsamo ali existe?

Fala comigo, ave triste!

Responde, se és capaz!"

Disse o Corvo, "Nunca Mais!"

16

"Profeta, bicho ruim!

Mas profeta mesmo assim

Se és pássaro ou diabo,

Pelo Céu que contemplamos

E pelo Deus que adoramos

Responde a esta pobre alma 
Carregada de pesar!

Existe um lugar no mundo

Mesmo no abismo profundo

Mesmo distante demais

Onde minh'alma cansada

Doente de tanta dor

Um dia volte a enlaçar

A jovem santificada

A donzela bem-amada

Que os anjos chamam Leonor?"

Disse o Corvo, "Nunca Mais".

17

"Seja este o nosso adeus,

Pássaro, ou inimigo!"

Gritei eu me levantando,

"Volta pra tempestade

Pras negras margens da Noite

Sem deixar nenhum sinal

Nenhuma pena, nem sombra

Dessa mentira, esse mal

Que a tua alma falou!

Deixa a minha solidão!

Deixa o busto de Minerva!

Solta meu coração!

Sai fora da minha porta

Vai embora daqui, ave torta

Vai sem olhar pra trás!

Disse o Corvo, "Nunca Mais!" 
LANDO, Isa M. Poe-tando o Corvo.

18

E ali está o Corvo, parado

Sempre quieto, só pousado

No busto de Palas Atena

Acima da minha porta.

Pelos olhos mais parece

Um demônio ali sonhando.

A lâmpada alumiando

A sua sombra me traz,

E a minha alma da sombra

Que flutua pelo chão

Não se erguerá - nunca mais! 